\title{
Preferensi Siswa Sekolah Menengah Atas terhadap Pencarian Informasi Keamanan Pangan Jajanan Anak Sekolah di Jakarta
}

\author{
Preferences of High School Students to Search School Snack Food Safety \\ Information in Jakarta
}

\author{
Martha Uli Intan Sari Sinaga ${ }^{1}$, Winiati P. Rahayu $\left.{ }^{1,2}\right)^{*}$, Yanti Kamayanti Latifa ${ }^{3)}$ \\ 1) Departemen Ilmu dan Teknologi Pangan, Fakultas Teknologi Pertanian, Institut Pertanian Bogor, Bogor \\ ${ }^{2)}$ South East Asian Food and Agricultural Science and Technology Center, Institut Pertanian Bogor, Bogor \\ 3) Badan Pengawas Obat dan Makanan Republik Indonesia
}

\begin{abstract}
School snack food (SSF) needs to be a priority of food safety guarantees because the consumption of SSF concerns the quality of the young generation. The method of delivering information on SSF safety is an effective way to increase awareness of food safety. This study aimed to explore the preferences of high school students for the search for food safety information. The survey was conducted to 100 SMA and MA students in DKI Jakarta; the results were processed by SPSS program using chisquare analysis. The survey results showed that $60 \%$ of students liked information from online media. Fifty percent of respondents considered the source of information as the primary consideration, and $46 \%$ believed the government was a trusted source. SMA students prioritized information sources, while MA students prioritized sources and the title of information, which were positively correlated $(p<0.05)$ with the infographic elements. Female students liked social networking and trusted the government and family. The male students preferred online media and trusted the government, family, and peers who are positively correlated with the type of media and trusted parties. The higher the level of parent's education, the more knowledge about the development of information technology which is positively correlated with the choice of media types for students.
\end{abstract}

Keywords: different test, food safety, preferences, SSF

\begin{abstract}
Abstrak. Pangan jajanan anak sekolah (PJAS) perlu menjadi prioritas penjaminan keamanan pangan karena konsumsinya menyangkut kualitas generasi muda. Metode penyampaian informasi keamanan PJAS merupakan hal yang efektif untuk meningkatkan kesadaran terhadap pentingnya keamanan pangan. Penelitian ini bertujuan untuk menggali preferensi siswa khususnya siswa SMA/MA dalam mencari informasi keamanan pangan. Survei dilakukan terhadap 100 siswa SMA dan MA di DKI Jakarta, hasilnya diolah menggunakan program SPSS dengan metode analisis chi square. Hasil survei menyatakan $60 \%$ siswa menyukai informasi dari media online, 50\% memilih sumber informasi menjadi pertimbangan utama, dan $46 \%$ menganggap pemerintah merupakan sumber yang dapat dipercaya atau didengarkan. Siswa SMA lebih mengutamakan sumber informasi, sedangkan siswa MA mengutamakan sumber dan judul informasi yang berkorelasi positif $(\mathrm{p}<0.05)$ terhadap pertimbangan utama dalam infografis. Siswa perempuan menyukai jejaring sosial dan mempercayai pemerintah dan keluarga, dibanding siswa laki-laki lebih menyukai media online dan mempercayai pemerintah, keluarga, dan teman sebaya yang berkorelasi positif dengan jenis media dan pihak yang dipercaya. Semakin tinggi tingkat pendidikan orang tua maka semakin mengikuti perkembangan teknologi informasi seperti media online yang berkorelasi positif terhadap pemilihan jenis media pada siswa.
\end{abstract}

Kata Kunci: keamanan pangan, PJAS, preferensi, uji beda

Aplikasi Praktis. Hasil penelitian ini dapat menjadi acuan dalam menyusun materi dan bentuk media
informasi keamanan pangan bagi lembaga atau instansi terkait keamanan pangan dengan memper-
timbangkan faktor-faktor yang memengaruhi preferensi dan kebutuhan remaja seperti jenis media yang
digunakan, kredibilitas penyedia informasi, visualisasi yang menarik, dan pengaruh orang sekitar terhadap
penangkapan informasi keamanan pangan.

\section{PENDAHULUAN}

Pangan merupakan kebutuhan primer setiap manusia. Setiap warga negara berhak mendapatkan pangan yang aman dan berkualitas. Pangan yang aman dan berkualitas jika pangan tersebut layak dikonsumsi dan terjamin keamanan pangannya. Kasus keracunan pangan masih banyak ditemukan hingga saat ini. Berdasarkan Laporan Badan Pengawas Obat dan Makanan (BPOM) 2017, tercatat sebanyak 53 Kejadian Luar Biasa (KLB) keracunan

Korespondensi: wpr@apps.ipb.ac.id 
pangan tahun 2017. Ditinjau dari jenis pangannya adalah masakan rumah tangga $(37.74 \%)$, pangan jajanan (24.53\%), diikuti pangan olahan dan jasa boga (13.21\%). Pangan jajanan menjadi terbanyak kedua penyebab KLB. PJAS termasuk ke dalam pangan jajanan dan tempat/ lokasi KLB keracunan pangan terbanyak kedua adalah lembaga pendidikan $(28.30 \%)$ setelah tempat tinggal di urutan pertama (BPOM 2017). Berdasarkan Laporan Akhir Hasil Monitoring dan Verifikasi Profil Keamanan PJAS Nasional tahun 2008, 98.9\% anak sekolah jajan di sekolah dan hanya $1 \%$ yang tidak pernah jajan di sekolah. Melihat tingginya persentase anak sekolah mengonsumsi PJAS menandakan perlunya perhatian terhadap keamanan PJAS.

Indonesia mulai memasuki bonus demografi pada tahun 2020, saat penduduk didominasi oleh penduduk usia produktif. Bonus demografi terjadi ketika proporsi jumlah penduduk usia produktif lebih dari $2 / 3$ dari total penduduk seluruh Indonesia. Bonus demografi tidak terlepas dari eksistensi remaja. Terjaminnya kualitas hidup dapat dilihat melalui kesehatan. Kesehatan dapat dijaga melalui gaya hidup yang baik yaitu mengonsumsi pangan yang aman dan berkualitas. Salah satu upaya yang dapat dilakukan adalah sosialisasi keamanan pangan. Sosialisasi dapat dilakukan secara langsung atau tidak langsung dengan memanfaatkan teknologi informasi internet. Menurut Kementerian Komunikasi dan Informatika (Kemkominfo) pada tahun 2014 dari 82 juta orang pengguna internet di Indonesia, $80 \%$ adalah remaja berusia $15-$ 19 tahun yang umumnya berada pada tingkat pendidikan sekolah menengah atas (SMA). Siswa SMA cenderung dapat memilih informasi sesuai preferensi dan kebutuhannya. Preferensi adalah pilihan suka atau tidak sukanya individu terhadap produk/barang/jasa yang digunakan atau dikonsumsi (Aiman et al. 2017). Penelitian ini bertujuan untuk mengetahui preferensi siswa SMA/MA terhadap pencarian jenis media, sumber, dan visualisasi informasi keamanan pangan sehingga dapat digunakan menjadi acuan untuk pemerintah atau penyedia informasi keamanan pangan dalam menyusun materi dan bentuk media informasi keamanan pangan dengan mempertimbangkan faktor yang memengaruhi preferensi dan kebutuhan remaja.

\section{BAHAN DAN METODE}

\section{Bahan}

Bahan yang digunakan adalah materi pembelajaran keamanan pangan dari BPOM berupa poster. Poster terdiri atas 3 tema antara lain Lima Kunci Keamanan Pangan, Cek KLIK (Kemasan, Label Izin edar, Kedaluwarsa), dan Jenis Bahan Kimia Berbahaya pada Pangan. Selain itu digunakan kuesioner untuk merekam jawaban responden (Widi 2011).

\section{Penentuan sampel responden (Sugiyono 2011)}

Penentuan sampel responden dilakukan menggunakan metode purposive sampling dengan kriteria inklusi atau kriteria subjek penelitian yang perlu dipenuhi oleh setiap anggota populasi yang menjadi sampel penelitian yaitu 1) Responden merupakan siswa/i SMA dan MA di DKI Jakarta 2) Responden pernah mencari informasi keamanan pangan. Jumlah responden dihitung menggunakan metode slovin dengan rumus seperti dibawah ini (Sugiyono 2011).

$$
\mathrm{n}=\frac{\mathrm{N}}{\left(1+\mathrm{N} \mathrm{e}^{2}\right)}=\frac{177331}{1+177331\left(0.1^{2}\right)}=99.99 \approx 100 \text { responden }
$$

dimana, $\mathrm{n}$ : jumlah sampel; $\mathrm{N}$ : jumlah populasi (siswa SMA dan MA DKI Jakarta); e : tingkat kesalahan pengambilan sampel yang dapat ditolerir.

\section{Penyusunan kuesioner (Pudjihastuti 2010)}

Pertanyaan pada kuesioner terdiri atas 4 bagian meliputi (1) Karakteristik responden (usia, jenis kelamin, asal sekolah, tingkat pendidikan orang tua); (2) Pengalaman dalam mencari informasi keamanan pangan; (3) Preferensi terhadap jenis, sumber dan karakteristik infografis keamanan pangan; (4) Preferensi terhadap tampilan media informasi. Pada bagian 4, terdapat infografis dengan 3 tema antara lain Poster 1 tentang Lima Kunci Keamanan Pangan, poster 2 tentang Cek KLIK, dan poster 3 berisi tentang Bahan Kimia Berbahaya yang terdapat pada Pangan. Masing-masing tema terdiri atas dua jenis poster keamanan pangan (poster A dan poster B). Salah satu poster berasal dari produk informasi yang dikeluarkan oleh BPOM namun logo atau tulisan BPOM yang tertera dihilangkan agar tidak memengaruhi pilihan pembaca, sedangkan poster lainnya dibuat oleh penulis dengan tampilan informasi sesuai dengan tren dan kesukaan anak muda. Pertanyaan dalam kuesioner berupa pertanyaan tertutup dengan alternatif jawaban yang disediakan.

\section{Pengambilan data (Widi 2011)}

Pengambilan data dilakukan menggunakan metode survei online menggunakan google form. Sebelum mengisi pertanyaan utama, dilakukan screening terlebih dahulu terhadap siswa yang memenuhi kriteria. Apabila responden memenuhi kriteria, maka responden dapat mengisi pertanyaan selanjutnya pada kuesioner, jika sebaliknya maka responden tidak dapat melanjutkan ke pertanyaan selanjutnya, atau dengan kata lain pengisian kuesioner berhenti. Jawaban responden atas semua pertanyaan dalam kuesioner kemudian dicatat atau direkam.

\section{HASIL DAN PEMBAHASAN}

\section{Sumber informasi keamanan pangan dan tindak lanjut}

Informasi keamanan pangan dapat diperoleh dari sosialisasi atau penyuluhan dari suatu lembaga/instansi terkait. Menurut hasil penelitian, responden yang pernah mengikuti penyuluhan keamanan pangan sebanyak 59\% yang diperoleh dari berbagai instansi/lembaga. Distribusi 
frekuensi responden memperoleh penyuluhan keamanan pangan dari lembaga/instansi tersebut dapat dilihat pada Tabel 1.

Tabel 1. Pengalaman responden terkait informasi keama-

\begin{tabular}{llc}
\multicolumn{2}{c}{ nan pangan } & \\
\hline \multicolumn{2}{c}{ Pengalaman Responden } & Respon (\%) \\
\hline Pihak yang & BPOM & 29 \\
memberi & Media cetak/elektronik & 25 \\
sosialisasi & Kemenkes RI & 17 \\
keamanan & Produsen makanan/minuman & 16 \\
pangan & Lainnya & 13 \\
Tindakan & Mendiskusikan dengan & 39 \\
responden & keluarga, rekan, atau teman & \\
setelah & Menghindari untuk mengon- & 35 \\
memper- & sumsi makanan/minuman \\
oleh infor- & tersebut & \\
masi kea- & Mencari sumber berita lain & 15 \\
manan & Memverifikasi informasi ke & 4 \\
pangan & lembaga yang berwenang & \\
& Tidak terlalu peduli dan tidak & \\
& $\begin{array}{l}\text { terpengaruh dengan informasi } \\
\text { tersebut }\end{array}$ & 3 \\
& $\begin{array}{l}\text { Menanyakan kebenaran } \\
\text { informasi kepada yang }\end{array}$ & 3 \\
& menyebarkan & \\
& Meneruskan berita/informasi & 1 \\
\hline & yang diterima & \\
\hline
\end{tabular}

Lembaga yang paling sering melakukan penyuluhan keamanan pangan adalah BPOM. Hal ini disebabkan BPOM merupakan instansi pemerintah yang bertugas dalam pengawasan pangan di Indonesia. Media cetak/ elektronik seperti majalah, buku, dan artikel merupakan media terbanyak kedua yang memberikan penyuluhan keamanan pangan. Wulandari dan Woro (2016) menyebutkan bahwa media cetak dan elektronik dapat digunakan untuk menyampaikan pesan yang bertujuan meningkatkan pengetahuan sebagai alternatif penyuluhan tatap muka atau langsung serta meningkatkan daya tarik. Kemenkes adalah lembaga pemerintah dibidang kesehatan yang berkaitan erat dengan kesehatan masyarakat sehingga Kemenkes mempunyai peran dalam mengadakan penyuluhan kesehatan melalui pangan yang dikonsumsi oleh masyarakat. Produsen makanan/minuman dianggap memegang peran untuk memberikan informasi keamanan pangan karena produsen makanan/minuman merupakan pihak yang paling bertanggung jawab pada keamanan produknya. Sumber lainnya adalah lembaga pendidikan seperti guru dan tim UKS. Hal ini didukung penelitian Manalu dan Su'udi (2016) yang menyatakan bahwa siswa SD di Kota Bekasi mendapat pembinaan keamanan pangan khususnya mengenai PJAS dari materi yang ada di pelajaran misalnya materi pelajaran IPA. Respon yang paling sering dilakukan setelah memperoleh informasi keamanan pangan adalah mendiskusikan dengan keluarga, rekan, atau teman yang juga. Hal ini diharapkan dapat menambah pemahaman terhadap materi yang didapat. Syifa et al. (2014) menyatakan seseorang yang kurang memiliki pengalaman terhadap suatu produk, jasa atau informasi cenderung mencari nasihat atau pendapat dari orang lain mengenai informasi tersebut. Keluarga, teman, atau rekan adalah pihak yang paling memberi pengaruh nyata terhadap pengambilan keputusan seseorang. Respon lainnya adalah bertindak menghindari konsumsi pangan yang dianggap berbahaya. Tindakan ini menggambarkan tindakan preventif yang dapat dilakukan responden agar terhindar dari bahaya kesehatan. Siswa lainnya mencari sumber berita lain, mencari kebenaran berita yang ramai dibicarakan dengan bertanya ke lembaga yang berwenang dan menanyakan kebenaran berita/informasi kepada pihak yang menyebarkan. Hal ini sejalan dengan penelitian yang dilakukan oleh Rahadi (2017) yang menyatakan sebagian besar responden setelah memperoleh informasi yang diperoleh melalui media sosial melakukan cross check terlebih dahulu terhadap kebenaran informasi yang mereka terima.

\section{Preferensi jenis media dan sumber informasi keama- nan pangan}

Preferensi responden terhadap jenis media yang digunakan dalam mencari informasi keamanan pangan dapat dilihat pada Tabel 2 .

\begin{tabular}{llc}
\multicolumn{2}{c}{ Tabel 2. Preferensi jenis media informasi keamanan pangan } \\
\hline \multicolumn{2}{c}{ Jawaban Responden } & Respon (\%) \\
\hline Jenis media & Media online & 60 \\
& Jejaring sosial & 33 \\
& Podcast & 5 \\
& TV & 2 \\
Pihak yang paling & Pemerintah & 46 \\
didengarkan atau percayai & Keluarga & 29 \\
& Guru & 12 \\
& Teman sebaya & 9 \\
& Lainnya & 4 \\
\hline
\end{tabular}

Jenis media yang paling banyak disukai responden untuk mencari informasi keamanan pangan adalah media online. Media online adalah bentuk aplikasi web yang menyerupai tulisan (yang dimuat sebagai posting) pada sebuah halaman web umum. seperti laman website, blog, dan Wikipedia. Hal ini sejalan dengan penelitian oleh Halim (2015), media online merupakan media yang paling banyak disukai remaja karena kecepatannya dalam menyediakan informasi yang diperlukan. Selain itu, jejaring sosial seperti facebook, youtube, instagram juga disukai siswa sebagai sumber berita. Jejaring sosial adalah situs berupa halaman web pribadi dan dapat terhubung dengan orang lain dari berbagai belahan dunia untuk berbagi konten komunikasi. Survei terhadap perilaku remaja yang berusia 13-19 tahun oleh Frontier Consulting Group (2012) diperoleh hasil bahwa 91.2\% remaja merupakan pengguna jejaring sosial aktif (Aprinta dan Dwi 2017). Podcast dan TV menjadi media yang paling sedikit disukai karena kurang instan dalam menyediakan informasi. TV adalah media telekomunikasi berupa gambar bergerak yang sifatnya one to many (satu untuk semua). Podcast berupa file-file audio dan video dengan berlangganan melalui layanan seperti iTunes dari Apple (Badri dan Antin 2015).

Pihak yang paling dipercayai atau lebih didengarkan dalam memberi informasi keamanan pangan adalah pemerintah karena dianggap informasi yang dikeluarkan akurat, dapat dipercaya, dan bersifat resmi. Pihak yang dipercayai lainnya adalah keluarga. Penelitian yang dilakukan oleh Syifa et al. (2014) yang menyatakan 
bahwa seseorang yang kurang memiliki pengalaman terhadap suatu produk, jasa atau informasi cenderung mencari nasihat atau pendapat dari orang lain mengenai informasi tersebut, dan keluarga adalah orang terdekat dan dapat memberi pengaruh terhadap pengambilan keputusan seseorang. Pihak yang dipercaya setelah keluarga adalah guru. Penelitian yang dilakukan oleh Halim (2015) tentang survei perilaku siswa untuk memastikan kredibilitas informasi di internet menemukan bahwa siswa mengukur kredibilitas informasi yang diterima dengan bertanya atau berdiskusi dengan guru. Guru dianggap lebih tahu dan mampu memberi tanggapan tentang informasi yang diterima.

Teman sebaya menjadi pihak paling dipercaya selanjutnya, hal tersebut dikarenakan teman sebaya dapat memberikan kepercayaan diri seseorang dan dapat memberi pengaruh terhadap pengambilan keputusan remaja (Syifa et al. 2014). Pihak yang paling sedikit dipercaya adalah influencer atau orang yang berpengaruh dibidang pangan. Hal ini disebabkan sebagian besar influencer hanya mempromosikan suatu produk atau merek untuk meningkatkan penjualan produk tersebut (Sugiharto et al. 2018) dan tidak banyak yang mengerti tentang keamanan pangan.

\section{Preferensi infografis keamanan pangan}

Infografis adalah suatu konsep penyajian informasi dengan menerapkan kreativitas, daya tarik, kesesuaian isi dan ilustrasi dan keefektifan waktu untuk menginterpretasikan informasi yang diberikan. Penggunaan infografis juga digunakan untuk menyederhanakan informasi yang kompleks menjadi lebih sederhana sehingga membuat pembaca tertarik terhadap informasi yang diberikan (Miftah et al. 2016). Terdapat beberapa pertimbangan pembaca untuk membaca suatu infografis diantaranya visualisasi, sumber, isi informasi, judul informasi, dan penggunaan bahasa. Hasil penelitian mengenai preferensi siswa memilih infografis keamanan pangan ditunjukkan pada Tabel 3.

Tabel 3. Pertimbangan unsur infografis

\begin{tabular}{lc}
\hline \multicolumn{1}{c}{ Unsur Infografis } & Respon (\%) \\
\hline Sumber informasi & 50 \\
Isi informasi & 22 \\
Judul informasi & 16 \\
Visualisasi & 8 \\
Bahasa & 4 \\
\hline
\end{tabular}

Sumber atau penyedia informasi menjadi pilihan pertama siswa dalam mempertimbangkan unsur infografis yang disukai. Penelitian yang dilakukan oleh Soenarno et al. (2015) menunjukkan adanya hubungan yang signifikan antara kredibilitas sumber terhadap kegunaan informasi. Kredibilitas sumber mampu memicu kepercayaan seseorang terhadap informasi yang diberikan bahkan tanpa mempedulikan isi informasi. Unsur infografis yang juga dipertimbangkan siswa adalah isi informasi.

Penelitian yang dilakukan oleh Soenarno et al. (2015) menunjukkan terdapat hubungan yang signifikan antara kualitas informasi dan kegunaan informasi. Kualitas informasi yang baik akan memberikan manfaat kepada pembaca dan pembaca akan menganggap informasi yang diterima lebih berguna. Preferensi unsur infografis selanjutnya adalah judul informasi. Menurut Oktiningtyas (2018), judul berita/informasi merupakan salah satu faktor yang memengaruhi ketertarikan terhadap isi majalah. Daya tarik yang diberikan judul dapat memengaruhi keputusan responden untuk melihat informasi yang diberikan lebih lanjut. Unsur infografis lainnya yang dipilih responden adalah visualisasi infografis. Menurut Novianto (2019), keefektifan infografis terletak pada visualisasi informasinya sehingga mampu memengaruhi pembaca untuk mau menangkap pesan yang terkandung dalam infografis. Bahasa menjadi pertimbangan terakhir responden mencari informasi keamanan pangan. Penggunaan bahasa yang mudah dimengerti memberikan kontribusi pada minat baca seseorang (Oktiningtyas 2018).

\section{Preferensi tampilan media informasi}

Bentuk media yang digunakan untuk menyebarkan informasi dalam penelitian ini adalah poster. Poster adalah sebuah produk informasi dengan kombinasi visual dan mampu menanamkan gagasan atau ide yang tertuang di dalam poster di dalam ingatan pembaca (Sudjana dan Rivai 2010). Poster didesain sesuai dengan preferensi remaja Hasil penelitian ditunjukkan pada Tabel 4.

Tata letak infografis menjadi pilihan terbanyak responden di semua tema infografis. Penelitian yang dilakukan oleh Arigia et al. (2016) menyebutkan bahwa penempatan tata letak menjadi elemen yang paling banyak disoroti oleh responden karena memengaruhi fokus informasi yang disampaikan. Penelitian tersebut membuktikan bahwa publik terbiasa membaca suatu informasi dari atas ke bawah atau dari kiri ke kanan. Kebiasaan inilah yang dapat memengaruhi fokus responden dalam membaca dan memahami infografis. Gambar/animasi menjadi alasan terbanyak kedua. Gambar/animasi biasanya digunakan untuk merepresentasikan teks atau tulisan. Adanya Gambar/animasi memberikan daya tarik pembaca supaya tidak jenuh dan bosan dengan informasi yang isinya terlalu banyak teks atau tulisan.

Hal ini sejalan dengan penelitian Saptodewo (2014), yang menyebutkan bahwa penggunaan gambar/animasi dapat menarik atensi pengamat sekaligus mempersuasinya. Infografis yang diilustrasikan dengan gambar yang kreatif dan menarik terbukti lebih menarik perhatian dan mudah dipahami oleh pembaca. Warna menjadi elemen infografis yang juga disukai. Menurut penelitian yang dilakukan oleh Indahsari dan Setyati (2012), remaja menyukai warna-warna cerah seperti warna pink, kuning, hijau yang memberikan kesan ceria. Alasan memilih lainnya adalah kemudahan untuk dipahami dan font/tipografi. Menurut Arigia et al. (2016), tipografi merupakan poin yang menjadi perhatian partisipan, ukuran huruf yang terlalu kecil membutuhkan usaha lebih untuk membacanya sehingga dapat menghambat pemahaman partisipan tipografi juga yang membuat informasi mudah dipahami. 
Tabel 4. Preferensi tampilan media informasi

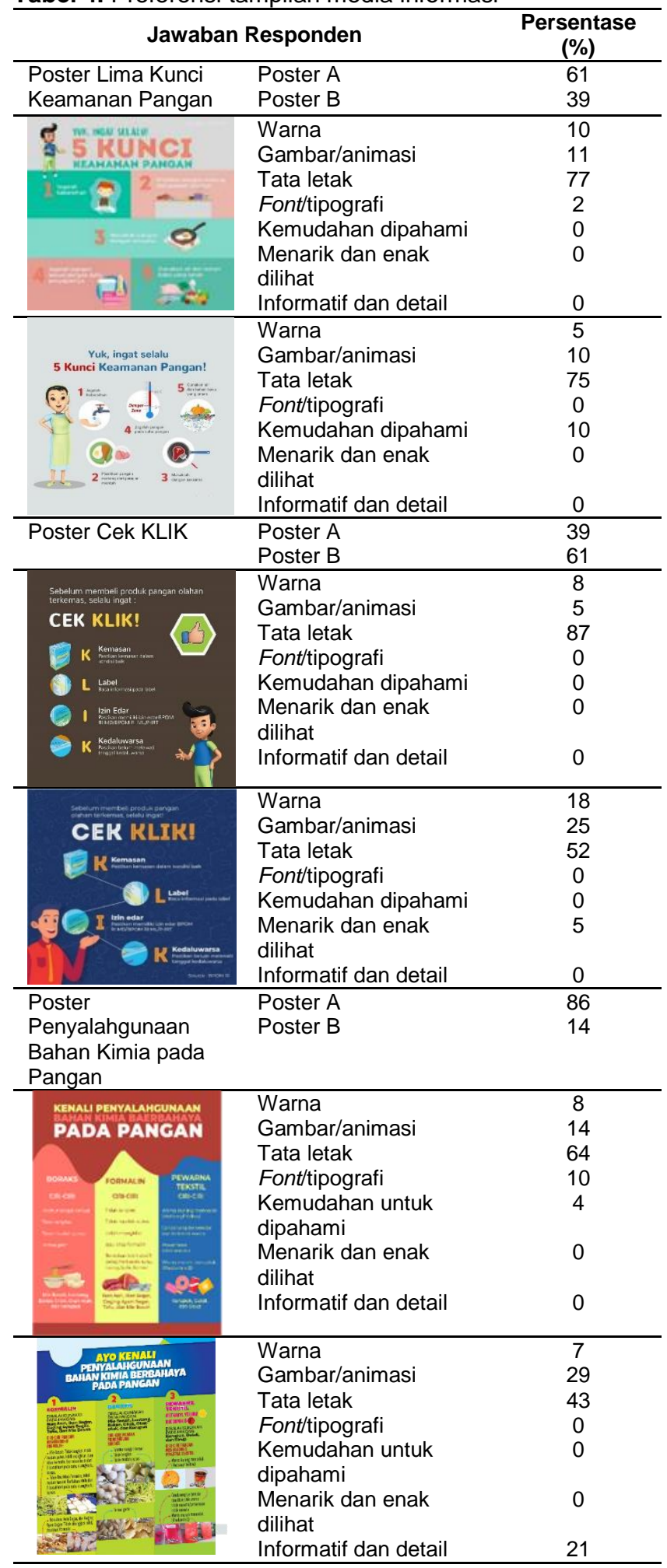

Karakteristik responden yang berpengaruh pada preferensi pencarian jenis, sumber, dan tampilan media

Karakteristik responden meliputi jenis kelamin, asal sekolah, usia, dan tingkat pendidikan orang tua yang dapat dilihat pada Tabel 5. Karakteristik responden merupakan ciri yang menggambarkan identitas responden dimana setiap responden memiliki karakteristik berbeda yang dapat dilihat dari segi umur, jenis kelamin, dan pendidikan (Santi 2012). Menurut Yoga dan Warmika
(2013), karakteristik individu dapat memengaruhi perilaku seseorang, hal ini dibuktikan adanya hubungan signifikan antara karakteristik individu yaitu usia dan tingkat pendidikan terhadap keputusan konsumen.

Tabel 5. Karakteristik responden

\begin{tabular}{lcc}
\hline \multicolumn{2}{c}{ Jawaban Responden } & Persentase (\%) \\
\hline Umur & 15 & 16 \\
& 16 & 29 \\
\multirow{4}{*}{ Jenis Kelamin } & 17 & 42 \\
\multirow{4}{*}{ Pendidikan orang tua } & 18 & 13 \\
& Laki-laki & 45 \\
& Perempuan & 55 \\
& SD-SMP & 4 \\
& SMA/SMK/MA & 48 \\
& S1/Diploma & 34 \\
& Pascasarjana & 14 \\
\hline
\end{tabular}

Hasil analisis uji statistik Chi Square pada Tabel 6 memperlihatkan adanya hubungan signifikan antara jenis kelamin dengan preferensi responden terhadap jenis media yang disukai dan pihak yang dipercayai dalam mencari informasi keamanan pangan ( $\mathrm{p}$ value $<0.05)$.

Tabel 6. Hasil uji chi square preferensi responden

\begin{tabular}{lccc}
\hline $\begin{array}{c}\text { Karakteristik } \\
\text { Responden }\end{array}$ & $\begin{array}{c}\text { Media } \\
\text { yang } \\
\text { Disukai }\end{array}$ & $\begin{array}{c}\text { Pihak yang } \\
\text { Dipercayai/Didengarkan }\end{array}$ & $\begin{array}{c}\text { Karakteristik } \\
\text { Infografis }\end{array}$ \\
\hline Asal sekolah & 0.126 & 0.156 & $0.008^{*}$ \\
Jenis kelamin & $0.011^{*}$ & $0.047^{*}$ & 0.066 \\
Usia & 0.656 & 0.718 & 0.751 \\
Pendidikan & $0.000^{*}$ & 0.889 & 0.922 \\
orang tua & Keterangan : " $m$ miliki korelasi (hubungan) positif $(\mathrm{p}$ value $<0.05)$
\end{tabular}

Preferensi laki-laki terhadap jenis media menunjukkan laki-laki menyukai media online, sedangkan perempuan menyukai jejaring sosial. Hal ini sejalan dengan penelitian Nur et al. (2014) yang menunjukkan adanya pengaruh yang signifikan antara jenis kelamin dengan perilaku konsumsi media pada remaja. Laki-laki cenderung lebih menyukai media online untuk mencari informasi, bermain game dan meluangkan sedikit waktu di jejaring sosial sedangkan perempuan lebih banyak menghabiskan waktu di jejaring sosial. Sebagian besar responden perempuan mempercayai pemerintah dan keluarga untuk menanyakan tentang informasi yang diterima dari internet, sedangkan responden laki-laki mempercayai pemerintah, keluarga, dan teman sebaya. Teman sebaya lebih dapat memengaruhi persepsi atau keputusan pada laki-laki dibandingkan pada perempuan. Hal ini sejalan dengan penelitian yang dilakukan oleh Sulistiowati (2015) bahwa kecenderungan laki-laki berinteraksi dengan teman sebaya lebih besar dari pada perempuan.

Tingkat pendidikan orang tua juga berkorelasi positif terhadap preferensi responden memilih media informasi untuk mencari informasi keamanan pangan. Mayoritas tingkat pendidikan orang tua responden berada pada tingkat pendidikan menengah-tinggi. Hasil penelitian menunjukkan kelompok usia 30 tahun ke atas dengan pendidikan SMA, tamat sarjana dan magister memilih online sebagai sumber informasi. Hal tersebut dapat merepresentasikan perilaku konsumsi media orang tua responden. Hasil penelitian sejalan dengan penelitian Nur 
et al. (2014) yang menyatakan terdapat hubungan yang signifikan antara pendidikan dan usia terhadap perilaku menggunakan media massa.

Perilaku orang tua dapat memengaruhi perilaku anak karena orang tua adalah sosok paling dekat dalam memberikan contoh kepada anak. Seorang anak cenderung akan mengikuti kelakuan orang tuanya. Kecenderungan tersebut terbentuk karena orang tua sebagai sosok pertama yang menjadi contoh bagi anak (Astuti et al. 2018). Asal sekolah (SMA/MA) berkorelasi positif dengan pertimbangan unsur infografis keamanan pangan. Sebanyak $68 \%$ siswa SMA mempertimbangkan sumber atau penyedia informasi keamanan pangan, hanya sebagian kecil yaitu 32\% yang memilih karakteristik infografis lainnya. Sementara yang menjadi pertimbangan siswa MA adalah sebanyak 64\% memilih sumber informasi dan isi informasi keamanan pangan, hanya sebagian kecil yaitu $36 \%$ yang memilih karakteristik infografis lainnya. Keduanya sama-sama mempertimbangkan sumber menjadi pilihan pertama. Hal tersebut didukung oleh penelitian (Soenarno et al. 2015) bahwa kredibilitas sumber menjadi pemicu utama kepercayaan seseorang terhadap informasi yang diberikan dari sumber tersebut meskipun belum mengetahui isi informasinya. Isi informasi juga menjadi pertimbangan siswa MA karena kualitas informasi yang baik akan memberikan manfaat kepada pembaca dan pembaca akan menganggap informasi yang diterima lebih berguna.

\section{KESIMPULAN}

Preferensi siswa dalam mencari informasi keamanan pangan adalah informasi yang berasal dari sumber yang terpercaya dan familiar ditelinga mereka. Media online dan jejaring sosial menjadi pilihan pertama dan kedua siswa dalam mengakses informasi. Faktor utama yang menjadi pertimbangan siswa dalam memilih infografis keamanan pangan berturut-turut adalah tata letak, gambar/animasi, warna, bahasa dan font/tipografi. Tingkat pendidikan orang tua memiliki hubungan signifikan terhadap media informasi pilihan siswa. Jenis kelamin memiliki hubungan signifikan dengan pihak yang dipercaya dan media informasi yang digunakan. Asal sekolah memiliki hubungan dengan karakteristik infografis yang menjadi pertimbangan utama siswa mengakses informasi keamanan pangan.

\section{DAFTAR PUSTAKA}

Aiman A, Handaka AA, Lili W. 2017. Analisis preferensi konsumen dalam pengambilan keputusan mem-beli produk olahan perikanan di Kota Tasikmalaya (studi kasus di Pasar Tradisional Cikurubuk, Kec. Mangkubumi). Jurnal Perikanan dan Kelautan. 8(1): 8-18.

Aprinta G, Dwi E. 2017. Hubungan penggunaan media sosial dengan tingkat kepekaan sosial diusia remaja.
Messenger 9(1): 65-69. DOI: 10.26623/themes senger.v9i1.428.

Arigia MB, Damayanti T, Sani A. 2016. Infografis sebagai media dalam meningkatkan pemahaman dan keterlibatan publik bank Indonesia. J Komunikasi. 8(2): 120-133.

Astuti D, Suryadi K, Nurbayani SK. 2018. Kontribusi orang tua dalam proses pergeseran gaya hidup anak. Sosietas 8(1): 478-484. DOI: 10.17509/sosietas. v8i1.12503.

Halim NA. 2015. Penggunaan media internet di kalangan remaja untuk mengembangkan pemahaman keislaman. J Risalah 26(3): 132-150.

Indahsari RD, Setyati E. 2012. Desain simple dan modern dalam perancangan website penjualan. J Ilmiah Teknol Informasi Asia 6(2): 26-35.

Manalu HS, Su'udi A. 2016. Kajian implementasi pembinaan pangan jajanan anak sekolah (PJAS) untuk meningkatkan keamanan pangan: peran dinas pendidikan dan dinas kesehatan kota. Media Litbangkes 26(4): 249-256. DOI: $10.22435 / \mathrm{mpk}$. v26i4.5734 .249-256.

Miftah MN, Rizal E, Anwar RK. 2016. Pola literasi visual infografer dalam pembuatan informasi grafis (infografis). J Kajian Informasi Perpustakaan 4(1): 87-94. DOI: 10.24198/jkip.v4i1.11635.

Novianto F. 2019. Proses Penerapan Kriteria Infografis sebagai Media Penyampai Informasi dalam Praktik Hubungan Masyarakat pada Direktorat Jenderal Hortikultura. [Disertasi]. Jakarta (ID): Universitas Kristen Indonesia.

Nur A, Pradekso T, Setyabudi D, Herieningsih SW, Surrayya N. 2014. Pengaruh usia, tingkat pendidikan, dan jenis kelamin terhadap perilaku konsumsi media Interaksi Online 2(4): 1-11.

Oktiningtyas P. 2018. Kemenarikan konten berita dalam menarik minat pembaca majalah bumi mina tani. J Litbang 14(2): 83-92. DOI: 10.33658/jl.v14i2.111.

Pudjihastuti I. 2010. Prinsip penulisan kuesioner penelitian. J Agribisnis Pengembangan Wilayah 2(1): 4356.

Santi NP. 2012. Hubungan karakteristik sosial demografi konsumen dengan responden terhadap stimuli komunikasi pemasaran (Produk Bancassurance AIA-BCA). E-J Ekonomi Bisnis Universitas Udayana 1(2): 124143.

Saptodewo F. 2014. Desain infografis sebagai penyajian data menarik. J Desain 1(1): 163-218.

Soenarno AR, Suharyono, Mawardi MK. 2015. Analisis pengaruh kualitas informasi dan kredibilitas sumber terhadap kegunaan informasi dan dampaknya pada adopsi informasi (studi pada masyarakat pengikut akun twitter resmi kaskus). J Administrasi Bisnis 25 (1): $1-8$. 
Sudjana dan Rivai A. 2010. Media Pengajaran. Bandung (ID): Sinar Baru Algensido.

Sugiharto SA, Ramadhana MR. 2018. Pengaruh kredibilitas influencer terhadap sikap pada merek (studi pada mahasiswa Fakultas Komunikasi dan Bisnis Universitas Telkom). J Ilmu Politik Komunikasi 8(2): 1-9. DOI: 10.34010/jipsi.v8i2.1333.

Sugiyono. 2011. Metode Penelitian Kuantitatif, Kualitatif, dan R\&D. Bandung (ID): Alfabeta.

Sulistiowati S. 2015. Hubungan antara Interaksi Teman Sebaya dengan Perilaku Pacaran pada Remaja. [Disertasi]. Surakarta (ID): Universitas Muhammadiyah Surakarta.

Syifa S, Sulistyowati, Musfar TF. 2014. Pengaruh keluarga dan kelompok referensi terhadap keputusan konsumen membeli kosmetika khusus pria (studi kasus merek nivea men di kota Pekanbaru). J Online Mahasiswa Fakultas Ekonomi 1(2): 1-15.

Widi RE. 2011. Uji validitas dan reliabilitas dalam penelitian epidemiologi kedokteran gigi. Stomatognatic J Kedokteran Gigi 8(1): 27-34.

Wulandari R, Woro O. 2016. Efek smartcards dalam meningkatkan pengetahuan, sikap, dan praktik dalam memilih pangan jajanan. J Health Education 1(1): 16.

Yoga SI, Warmika GK. 2013. Hubungan karakteristik demografi dengan perilaku keluhan konsumen. E-J Manajemen Universitas Udayana 2(9): 1106-1124.

JMP-04-20-08-Naskah diterima untuk ditelaah pada 15 Maret 2020. Revisi makalah disetujui untuk dipublikasi pada 20 April 2020. Versi Online: http://journal.ipb.ac.id/index.php/jmpi 
